【カテゴリーII】

\title{
大変形域における一般構造用鋼 SS400材の塑性履歴特性 "HYSTERESIS LOOP CHARACTERISTICS OF STRUCTURAL CARBON STEEL SS400 IN VERY LARGE PLASTIC ZONES
}

中島伸幸*, 山田稔**

Nobuyuki NAKAJIMA and Minoru .YAMA.DA

In order to make clear the fundamental hysteresıs loop charactenstics of structural carbon steel SS400 in very large plastic zones, axial cyclic loading tests are carned out, controlled by the local longitudinal strain amplitudes. The shape of hysteresis loops of the nominal stress-local longitudinal strain relationship keeps the symmetrcal shape untıl the strain amplitude $30 \%$ and the nomınal 'stress and the true stress coincide also. untl $30 \%$. The nominal strain and the true strain concide until $10 \%$. The stress at the defined strain of hysteresis.loops becomes larger than the stress at the first virgin loading strain over 5.0\%o. For the application of mechanical charactenstics to the analysis, there are presented already many models. As a result of cmpanson of hysteresis loops from test results with Ramberg-Osgood model, I-K model (Isotropic -Kinematic hardening model), it becómes cleare that there exist naturally limits of application of these models.

Key words: Hysteresis loop, Plastuc zone, Local strain, Ramberg-Osgood model, $I-K$ model 履歴ループ， 塑性域，局所歪み，ランベルグーオズグッドモデル，I－K.モデル。

1. 序

土木・建築構造物が大地震時にうける変形は、ひずみ履歴研究対 象として従来研究されできた破断寿命が $10^{2} \sim 10^{4}$ 回となるひずみ振 幅の領域よりもはるかに大きい。

筆者らは、既報において一般構造用鋼材が $10^{0} \sim 10^{1}$ 回領域の超低 サイクル大ひずみをうけたときの破断現象を検討し、円柱形供試体 と砂時計形供試体について、塑性域におけるポアソン数は約 2.5 と なり、非圧縮性仮定が充たされないことを確認した。塑性域におけ るポアソン数の変化は他の鋼材においても確認されている。このこ とは塑性域における非圧縮性仮定を前提とし、最大、最小負荷時の 直径 $d$ および $d_{0}$ と断面積 $A$ および $A_{0}$ を用いであらわされる真ひずみ、

$$
\varepsilon_{t}=\ln \left(A_{0} / A\right)=2 \ln \left(d_{0} / d\right)
$$

の定義が不明確なものであることをあらうわている。

一般にはひずみ振幅領域の如何をを問わず(1)式を用いて径方向の ひずみ量の変化から、軸方向のひずみが換算されている。しかし、 大変形領域においては供試体標点間点における一様な引張および圧 縮が期待できず、破断寿命が $10^{2} \sim 10^{4}$ 回となるひずみ振幅の領域で の定ひずみ交番繰返し載荷試験から得られる、軸方向と径方向の安
定した履歴ループとは異なる現象が生じる。こうした大変形領域に おける供試体中央部の軸方向ひずみと径ひずみ、および供試体全体 の公称ひずみの変化量を同時に検討した例はない。

本研究では一般構造用鋼SS400材が、1 $10^{0} \sim 10^{1}$ 回のひずみ領域で 破断に至る超低サイクル大ひずみをうけたときの塑性履歴特性を供 試体中央部の軸方向ひずみと径ひずみ、および供試体全体の公称ひ ずみを用いて明らかにしようとするものである。

\section{2. 供試体および樲験方法}

供試材料は一般構造用鋼材SS400である。Fig.1に供試体の形状を 示す。供試部の標点間距離は供試体直径D (=11.3mm) に対して $2.5 \mathrm{D}$ とた。これは引張試験時に端部拘束による供試体中央部への 影響が少なく、圧縮試験時に横ずれの発生が少ないプロポーション だからである。10)

奏験は定ひずみ振幅引張圧縮交番繰返し載荷試験を片側振幅 $\varepsilon_{l a}=$ 1.5\%o, 2.5\%o, 4.0\%o, 5.0\%o, 7.5\%o, 10\%o, 20\%o, 30\%o, 40\%o, 50\%o で 行った。ひずみの制御は供試体中央部に貼付したびずみゲージ (W.S.G.) により、材軸中央部局所軸ひずみ $\left(\varepsilon_{l}\right)$ で行った。 測定装置の設置状況をFig.2に示す。供試体全体の軸方向変形は 円周の $120^{\circ}$ 方向にダイヤルゲージ（D.G.[=1/100mm]）を 3 個配置 しておこなった。中央部の局所ひずみは供試体中央部の円周を $60^{\circ}$
* 株新進 工修

** 神戸大学 名誉教授(前関西大学教授) ・工博
Shın Shın Co, Ltd, M Eng

Prof Em, Kobe Univ., Dr Eng 


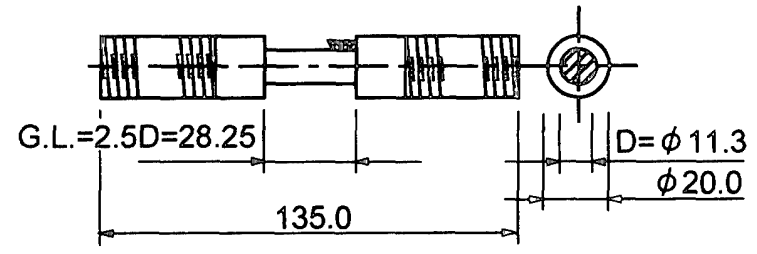

Fig.1 供 試 体

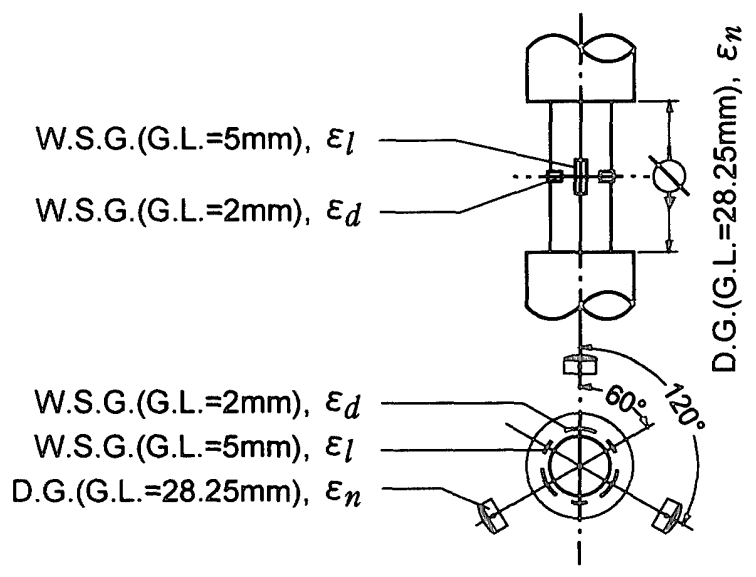

Fig.2 歪みゲージおよび変位計のセットアップ

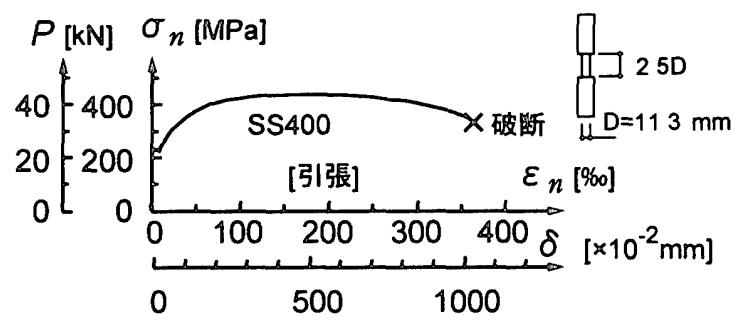

Fig.3 2.5D円柱形供試体一方向引張破断試験

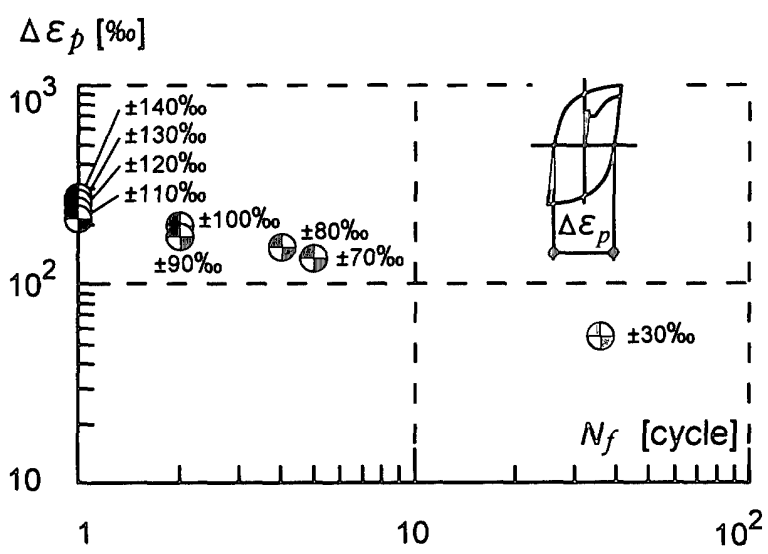

Fig.4 公称塑性歪み振幅 $\left(\varepsilon_{p}\right)$ 一破断繰返し数 $\left(N_{f}\right)$ 関係 一初引張載荷（SS400）-
で分割し、中央部局所軸ひずみ $\left(\varepsilon_{l}\right)$ に標点距離（G.L.）5mm、 径ひずみ $\left(\varepsilon_{d}\right)$ には標点距離 $2 \mathrm{~mm}$ のひずみゲージを交互に3枚ずつ 貼付して測定した。F1g.3に2.5D柱形供試体による単調引張試験 の結果を示す。

\section{3. 大变形領域の定酸}

Fig.4はSS400材の初引張載荷に始まる引張圧縮交番繰返し載荷疲 労試験の結果喜公称望性歪み振幅 $\left(\Delta \varepsilon_{p}\right)$ 一破断サイクル数 $\left(N_{f}\right)$ 関係で両対数上に示したものである。公称ひずみ振幅 $\varepsilon_{n a}= \pm 30$ $\%$ の実験は供試体端部で破断したものであるが、超低サイクル疲 労破塄においてもManson-Coffinの損傷エネルギー仮説がほぼ適合 するこことを洘えると、公称ひずみ振幅 回で破罗にいたる大変形域になると考えられる。

\section{4. 塑性殿歴ループの形状}

従来の塑性履歴ループに関する研究は主として真応力ー真ひずみ 関係で議論されることが多かった。しかし、真応力は大地霞を想定 した大塑性域における履歴ループの表現は真応力によるよりも、公 称応力による表現の方が構造物の耐力低下を評価する上で都合がよ い。大塑性域における履歴ループの形状を公称応力によって表現す ると原点対称性を失うという報告例はあるが、それがどの程度のひ ずみ領域から始まるのかについては明らかにされていない。本研究 ではまず中央部局所軸ひずみ $\left(\varepsilon_{l}\right)$ に対する、真応力 $\left(\sigma_{t}\right)$ と公 称応力 $\left(\sigma_{n}\right)$ の履歴ループ形状を比較する。

Fig.5は $\sigma_{t}-\varepsilon_{l}$ 関保で、中央部局所軸ひずみ掁幅 $\varepsilon_{l a}=10 \%$, 20\%，30\%o，40\%，50\%。を示している。真応力による表現の場 合、大塑性域においても、履歴ループは原点対称性を失わないこと がわかる。Fig.6は $\sigma_{n}-\varepsilon_{l}$ 関係で、中央部局所軸ひずみ振幅

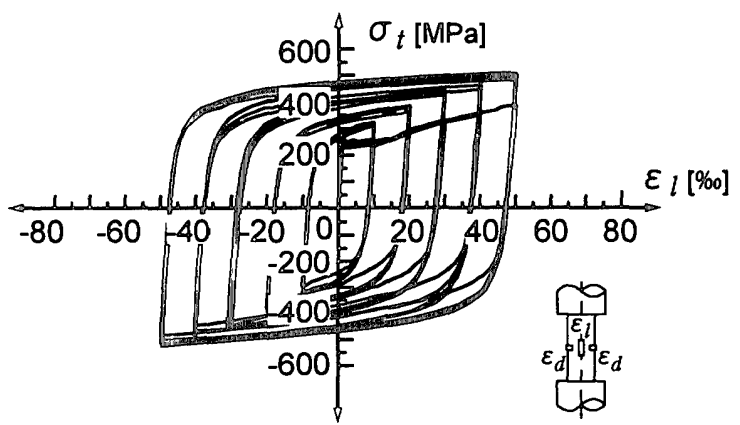

Fig.5 真応力 $\left(\sigma_{t}\right)$ 一局所軸歪み $\left(\varepsilon_{l}\right)$ 関係 [ $\varepsilon_{l a}=10 \%$, 20\%o, 30\%, 40\%, 50\%o]

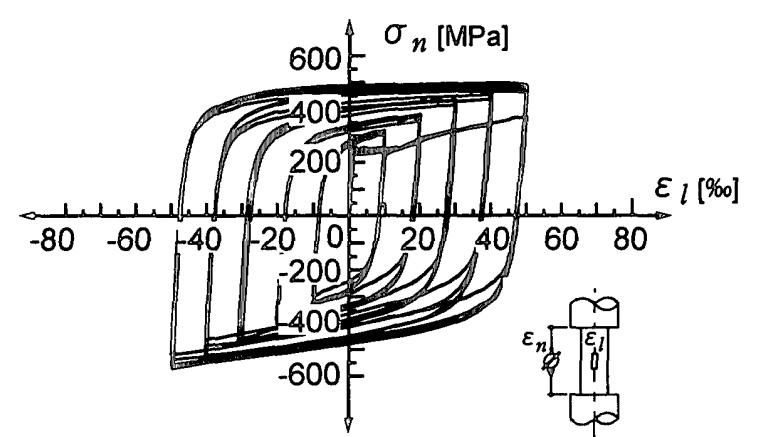

Fig.6 公称応力 $\left(\sigma_{n}\right)$ 一局所軸阷み $\left(\varepsilon_{l}\right)$ 関係 [ $\varepsilon_{l a}=10 \%, 20 \%, 30 \% 0,40 \%, 50 \%$ ] 

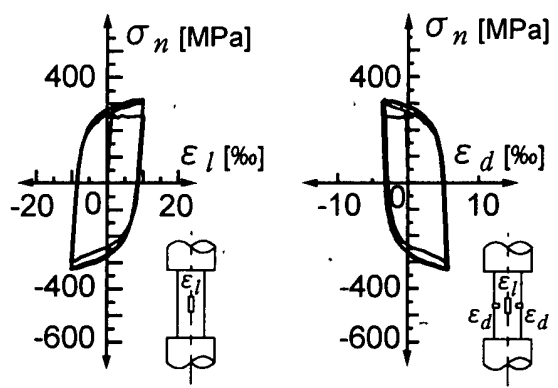

(a) $\sigma_{n}-\varepsilon_{l}$ 関係 (b) $\sigma_{n}-\varepsilon_{d}$ 関係

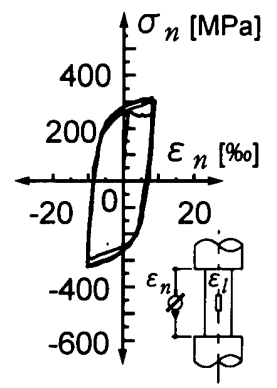

(c) $\sigma_{n}-\varepsilon_{n}$ 関係

Fig.7 中央部局所軸ひずみ振幅 $\left(\varepsilon_{l a}\right)=10 \%$

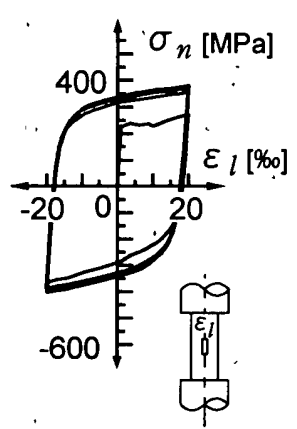

(a) $\sigma_{n}-\varepsilon_{l}$ 関係

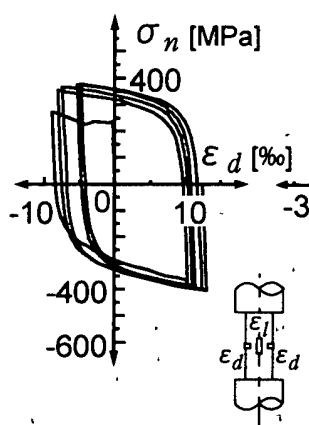

(b) $\sigma_{n}-\varepsilon_{d}$ 関係

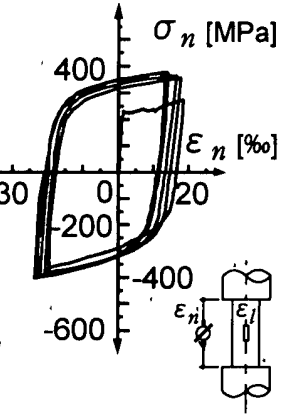

(c) $\sigma_{n}-\varepsilon_{n}$ 関係

Fig.8 中央部局所軸ひずみ振幅 $\left(\varepsilon_{l a}\right)=20 \%$

$\varepsilon_{l a}=10 \%, 20 \%, 30 \%, 40 \%, 50 \%$ を示している。図より、ループ の形状は40\%。あたりから原点対称性がく著しく失われていること

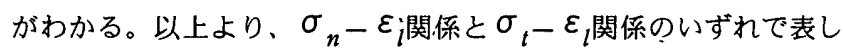
ても、ひずみ振幅 $30 \%$ くらいまではループの形状にほとんど差異 はないが、40\%oあたりから $\sigma_{n}-\varepsilon_{l}$ 関係で履歴ループの原点対称性 が著しく失われることがわかる。

5 局所部の履歴ループと全体の履歴ループの比較

塑性疲労試験に慣用されている、Manson-Coffin形の砂時計形供 試体によるひずみ制御で用いられる軸方向真歪みは計測された中央 部の径方向ひずみから供試体形状に応じた式によってポアソン数を 用いて換算された値によるのが一般的である。。

塑性域における非王縮性仮定に基づく真ひずみが、同時に測定さ れた公称ひずみと一致しないという報告例はあるが、実際の径方向 ひずみと局所的な軸方向ひずみおよび、供試体全体のひずみの関係 について直接計測された例はない。また、所定振幅時に与えられる ひずみ量が大きくなるにしたがって生じる、供試体全体のひずみ量と 供試体中央部の局所的なひずみ量との差についても明らかにされていな い。そこで、これら 3 つのひずみ量の変化についても比較検討を加える。

\section{1 中央部局所軸ひずみ制御試験と公称ひずみ制御試験}

Figs.7〜9は供試体中央部局所軸ひずみ振幅 ( $\left.\varepsilon_{l a}\right)$ で制御した定 ひずみ振幅引張圧縮交番繰返し試験の結果である。

Fig.7は $\varepsilon_{l a}=10 \%$ の結果で、Fig.7(a)は公称応力 $\left(\sigma_{n}\right)$-局所軸 ひずみ $\left(\varepsilon_{l}\right)$ 関係、Fig.7(b)はそのどきの公称応力 $\left(\sigma_{n}\right)$-径ひ

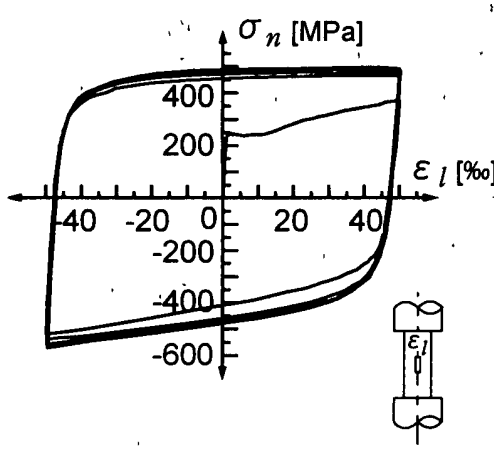

(a) $\sigma_{n}-\varepsilon_{l}$ 関係

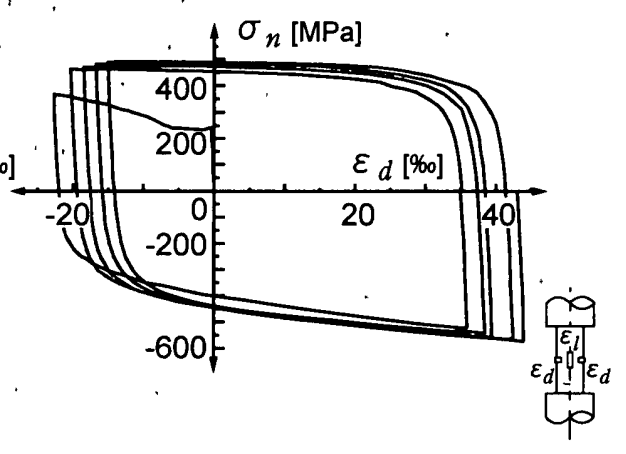

(b) $\sigma_{n}-\varepsilon_{d}$ 関係

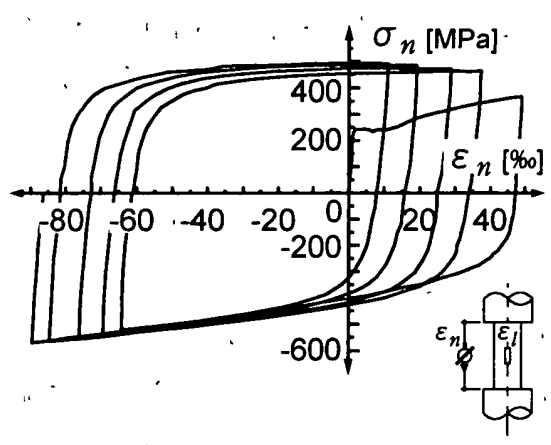

(c) $\sigma_{n}-\varepsilon_{n}$ 関係

Fig.9 中央部局所軸ひずみ振幅 $\left(\varepsilon_{l a}\right)=50 \%$

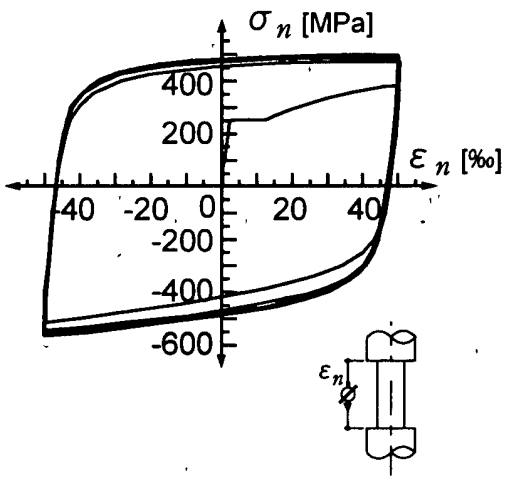

(a) $\sigma_{n}-\varepsilon_{n}$ 関係

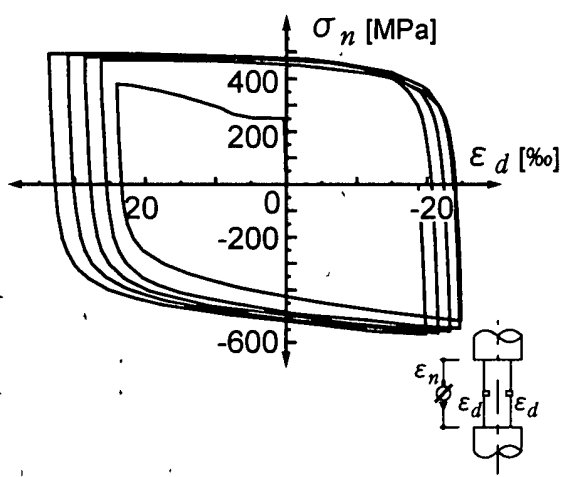

(b) $\sigma_{n}-\varepsilon_{d}$ 関係

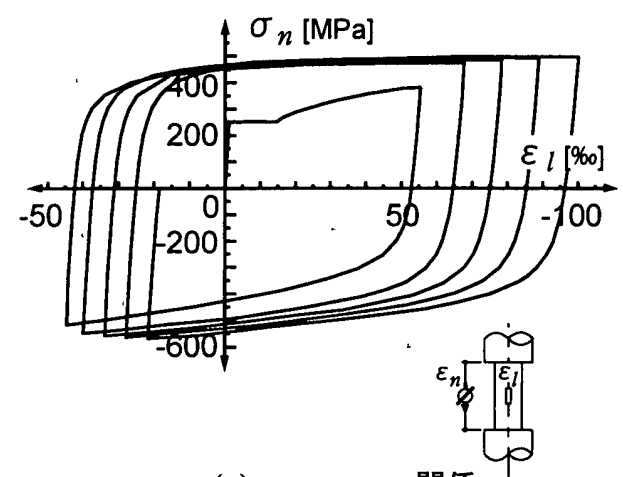

(c) $\sigma_{n}-\varepsilon_{l}$ 関係

Fig.10 公称ひずみ振幅 $\left(\varepsilon_{n a}\right)=50 \%$ 
ずみ $\left(\varepsilon_{d}\right)$ 関係、同じく $F_{1 g} .7(c)$ は公称応力 $\left(\sigma_{n}\right)$ 一公称ひずみ $\left(\varepsilon_{n}\right)$ 関係を示している。Fig.8は $\varepsilon_{l a}=20 \%$ の結果で、Fig.8(a)は $\sigma_{n}-\varepsilon_{l}$ 関係、Fig.8(b)はそのときの $\sigma_{n}-\varepsilon_{d}$ 関係、同じくFig.8(c) は $\sigma_{n}-\varepsilon_{n}$ 関係を示している。Fig.9は $\varepsilon_{l a}=50 \%$ の結果で、Fig.9 (a)は $\sigma_{n}-\varepsilon_{l}$ 関係、Fig.9(b)はそのときの $\sigma_{n}-\varepsilon_{d}$ 関係、同じく Fig.9(c)は $\sigma_{n}-\varepsilon_{n}$ 関係を示している。

Fig.7(a)とFig.7(c)を比べると、局所軸ひずみ（ $\left.\varepsilon_{l}\right)$ と供試体全体 のひずみ（ $\varepsilon_{n}:$ 公称ひずみ）がほぼ一致しており、履歴ループの 形状がほぼ等しくなっている。しかし、F1g.8(a)とF1g.8(c)を比べる と、 $\varepsilon_{n}$ が縮み側に増加し始めている。この傾向はF $19.9(\mathrm{a})$ と $\mathrm{F}_{1} \mathrm{~g} .9$ (c)を比べると、より顕著になっていることがわかる。

径方向のひずみ $\left(\varepsilon_{d}\right)$ はFig.7(b)に示すように $\varepsilon_{l a}=10 \%$ では安 定した履歴ループを表しているが、Fig.8(b)に示すように $\varepsilon_{l a}=20$ \%oでは伸び側に増加し始めている。この傾向はFig.9(c)に示すよう に $\varepsilon_{l a}=50 \%$ でより顕著になっていることがわかる。

以上より、中央部局所軸ひずみ振幅 $\left(\varepsilon_{l a}\right)$ を一定にすると $\varepsilon_{l a}$ $=10 \%$ を越えるひずみ領域では供試体全体が縮みだし、その傾向 は大変形域でより顕著となることがわかった。

Fig.10は公称ひずみ振幅 $\varepsilon_{n a}=50 \% 0$ で制御した定ひずみ振幅引張 圧縮交番繰返し試験の結果である。Fig.10(a)は公称応力 $\left(\sigma_{n}\right)-$ 公称ひずみ $\left(\varepsilon_{n}\right)$ 関係、Fig.10(b)はそのときの公称応力 $\left(\sigma_{n}\right)-$ 径ひずみ $\left(\varepsilon_{d}\right)$ 関係、同じくFig.10(c)は公称応力 $\left(\sigma_{n}\right)$ - 局所軸 ひずみ（ $\left.\varepsilon_{l}\right)$ 関係を示している。中央部局所軸ひずみ振幅で制御 したFig.9と比較すると、Fig.10(b)では径方向のひずみ $\left(\varepsilon_{d}\right)$ が縮 み方向に増加し、Fig.10(c)では中央部局所軸ひずみ $\left(\varepsilon_{l}\right)$ が伸び方 向に増加している。

以上より、大変形域において、公称ひずみ振幅 $\left(\varepsilon_{n a}\right)$ を一定 にすると中央部局所軸ひずみ $\left(\varepsilon_{l}\right)$ が伸びることがわかった。

Fig.11はFig.9とFig.10をもとにした、载荷サイクル数（N）が 5 回目にいたるまでの中央部の累積局所ひずみ $\left(\Sigma \varepsilon_{l}\right)$ とポワソン 数 $(m)$ の関係図である。実線は中央部の局所軸ひずみ振幅制御に よるもので、ポワソン数が2.0よりも減少する傾向がみられる。一

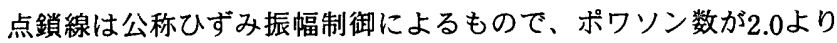
も增加する傾向がみられる。

Fig.7に示したように、破断までの繰返し数が $10^{1}$ 回を越える変形 域では公称ひずみと局所軸ひずみの履歴ループはほぼ同じ挙動を示

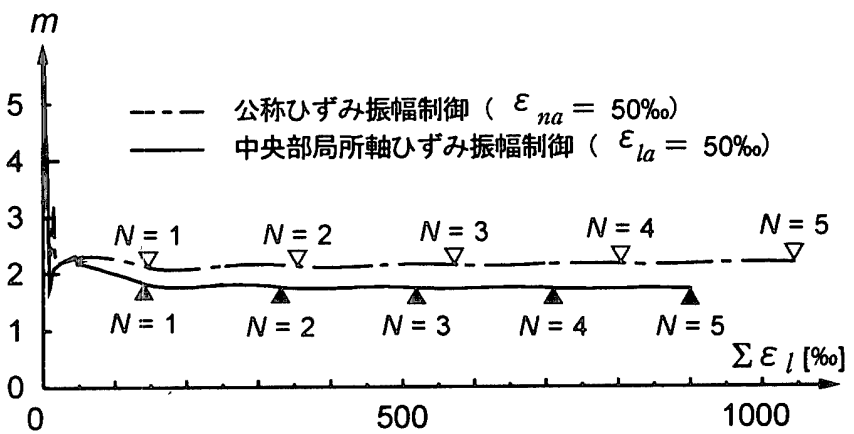

Fig.11 累積局所軸歪み $\left(\sum \varepsilon_{l}\right)$ ーポワソン数 $(m)$ 関係

し、径方向ひずみの履歴ループも伸び方向や縮み方向に偏って増加 することがない。このような変形域では一様な引張および圧縮変形 がなされているといえる。しかし、Figs.9〜10に示したような、1 $10^{0}$ 〜 $10^{1}$ 回で破壊にいたる大変形域では一様な引張および瓦縮変形が 期待できす、供試体中央部にくびれや膨らみが発生することにな る。この場合、供試体中央部の局所軸ひずみでひずみ振幅制御を行 うと、径方向の伸び変形にエネルギーが消費され、供試体中央部の 径ひずみに伸びが累積され、供試体全体が縮み、塑性域での体積が 減少すると考えられる。また、供試体全体の公称ひずみでひずみ振 幅制御を行うと、軸方向の伸び変形にエネルギーが消費され、供試 体中央部の軸ひずみに伸びが累積し、供試体中央部が伸び、塑性域 での体楥が增加すると考えられる。

\section{6 塑性閵歷のモデル式による近似表現}

塑性域履歴曲線を近似式により表現して解析に利用するため多く のモデルが提唱され、式の運用例が報告されている。しがし、定ひ ずみ振幅疲労試験におけるループは振幅が大きな場合と小さな場合 とではその形状が特にBauschinger効果域で異なり、モデル式はそ の適用の際に十分な注意が払われねばならない。近時、構成式と称 されるモデルは殆ど物理的意味をもたず、単に解析の方便としての み意味を持つものが殆どである。従って、モデルは解析の目的に応 じて取捨選択し、その適用範囲が明示されて初めて意味を持つこと となる。本研究ではそうした適用範囲を明示するために、各モデル のパラメーターを実験結果に近づくように選択し、その一般構造用 鋼への適用について若干例示する。

6.1 I-K bi-Linear モデル ${ }^{16) 18) 19)}$

Fig.12は移動硬化十等方硬化、軟化モデル（Isotropic-Kınematic hardening model: 以下、I-Kモデルと呼ぶ）の基本概念を示す。

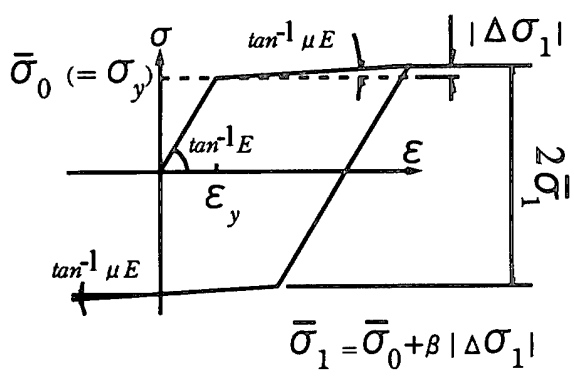

Fig.12 I-K bi-Linear モデル概念図

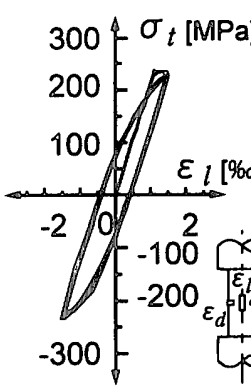

(a) $\varepsilon_{l a}=1.5 \%$

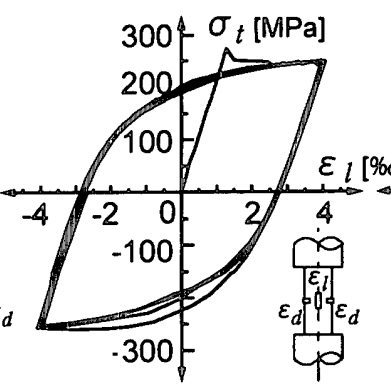

(b) $\varepsilon_{l a}=40 \%$

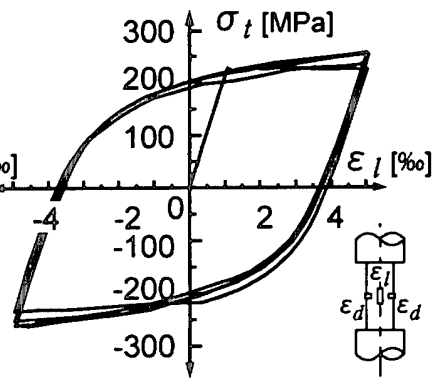

(c) $\varepsilon_{l a}=5.0 \%$

Fig.13 真応力 $\left(\sigma_{t}\right)$ 一局所軸歪み $\left(\varepsilon_{l}\right)$ 関係履歴ループ 
Table.1 変数 $\beta, \beta a, \dot{\beta} b, \mu \quad(\mathbf{S S 4 0 0})$

\begin{tabular}{|c|c|c|c|c|c|}
\hline Model & \multicolumn{2}{|c|}{ bi-Lınear } & \multicolumn{3}{|c|}{ 直 列 } \\
\hline$\varepsilon_{l a}$ & $\mu$ & $\beta$ & $\mu$ & $\beta a$ & $\beta b$ \\
\hline $1.5 \% \circ$ & 0.01 & 0.00 & 0.05 & -8.00 & 0.80 \\
$2.5 \% \circ$ & 0.01 & 0.00 & -0.02 & -8.00 & 0.80 \\
$4.0 \%$ & 001 & 0.00 & 0.01 & -4.00 & 0.80 \\
$5.0 \% \circ$ & 0.01 & 0.70 & 0.01 & -200 & 085 \\
$7.5 \% \circ$ & 001 & 0.80 & 0.01 & -1.00 & 0.85 \\
$10.0 \% \circ$ & 001 & 0.80 & 0.01 & -0.50 & 0.90 \\
$20.0 \% \circ$ & 0.01 & 070 & 001 & 0.20 & 0.80 \\
$30.0 \% \circ$ & 0.01 & 0.70 & 0.01 & 0.20 & 080 \\
$40.0 \% \circ$ & 0.01 & 0.70 & 0.01 & 0.20 & 0.75 \\
$50.0 \% \circ$ & 0.01 & 0.70 & 0.01 & 0.50 & 0.70 \\
\hline
\end{tabular}

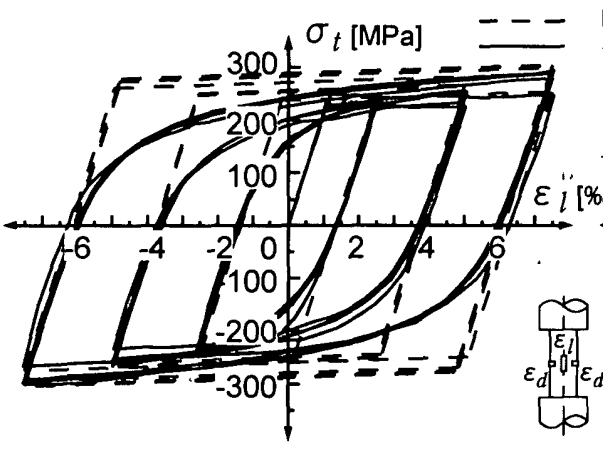

(a) $\varepsilon_{l a}=25 \%, 5.0 \%, 7.5 \%$

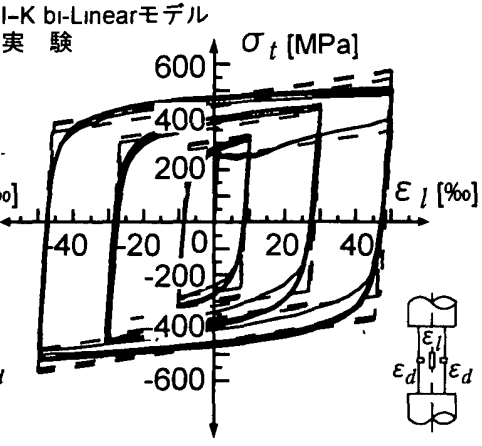

(b) $\varepsilon_{l a}=10 \%, 30 \%, 50 \%$

Fig.14Ｉ-K bi-Linearモデルと実験結果の比較

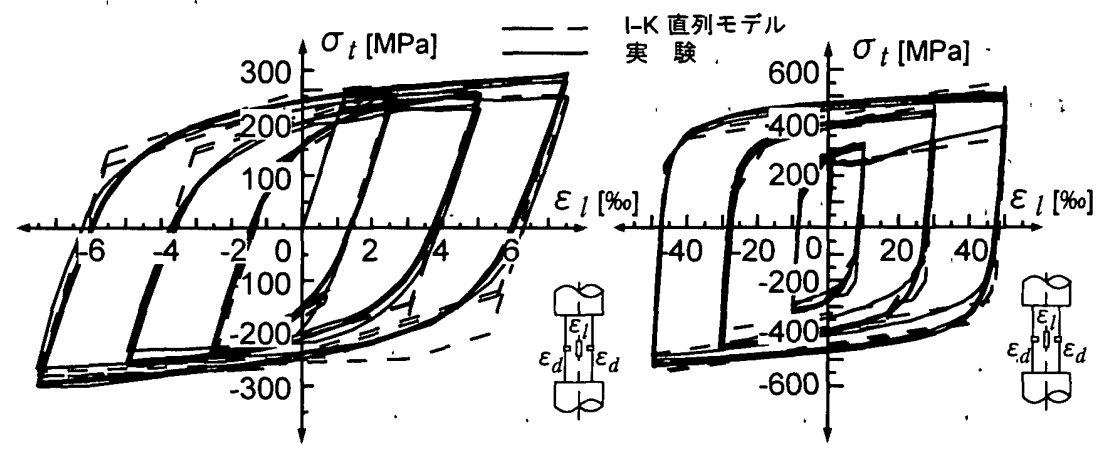

(a) $\varepsilon_{l a}=2.5 \% 0,5.0 \% 0,7.5 \%$

(b) $\varepsilon_{l a}=10 \%, 30 \%, 50 \%$

Fig.16 I-K 直列モデルと実験結果の比較

硬化パラメータ $\beta$ を変えて相当応力 $\bar{\sigma}$ を決定し、 bi-Linear型の応力 ーひずみ関係を描くものである。F1g.13にSS400材を用いて行った 供試体中央部局所軸ひずみ振幅 $\left(\varepsilon_{l a}\right)$ 制御による定ひずみ振幅引 張圧縮交番繰返し載荷試験の結果を、真応力 $\left(\sigma_{t}\right)$ 一局所軸ひず み $\left(\varepsilon_{l}\right)$ 関係で示した。F1g.13(a)は $\varepsilon_{l a}=1.5 \%$ の結果、F1g.13(b) は $\varepsilon_{l a}=4.0 \%$ の結果、Fig.13(c)は $\varepsilon_{l a}=5.0 \%$ の結果を示している。

Fig.13(c)より、履歴ループの所定ひずみにおける応力は $5.0 \% \circ く$ らいから処女載荷時の所定ひずみにおける応力よりも增加すること がわかる。しかし、F1gs.13(a),(b)に示すように、5.0\%。より振幅の小 さい領域では所定ひずみにおける履歴ループの応力は降伏棚までも どり、 5 回程度のサイクル数では塑性軟化も生じてい) より、IーKモデルの軟化モデルは一般構造用鋼SS400材の履歴ルー プには適用不可能であることがわかる。

Table.1は夷験結果にモデルを近づけるための計算に用いた $\mu$ と $\beta$ の值である。Fig.14はTable.1に示す $\mu$ と $\beta$ を用いて計算した結果 を $\sigma_{t}-\varepsilon_{l}$ 関係と比較したものである。Fig:14(a)は2.5\%o， 5.0\%o, $7.5 \%$ との比較を示し、Fig.14(b)は 10\%o, 30\%o, 50\%oとの比較を示 している。10\%。以下の領域では計算值が実験值を大きくはずれる が20\%o～50\%oの間では $\mu=0.01 ， \beta=0.7$ とることによりおおまか にフォローできるといえる。

\section{I-K 直列モデル ${ }^{16) 19)}$.}

Fig.15に示すように $(a),(b) 2 つ の$ 要素を直列につなぎ、各要素に それぞれ $\mathrm{I}-\mathrm{K}$ b1-Linear形の応力ーひずみ関係をもたせると、 tri-Linear形の応力ーひずみ関倸を描くことができる。Fig.16は $\mu a=5 \mu /(1-5 \mu), \mu b=5 \mu /(9+5 \mu)$ として、Table.1
に示す $\mu, \beta a, \beta b$ を用いて計算した結果を $\sigma_{t}-\varepsilon_{l}$ 関係と比較した ものである。F1g.16(a)は2.5\%o, 5.0\%o, 7.5\%。との比較を示し、F1g.16 (b)は 10\%o, 30\%o, 50\%。との比較を示す。Table.1に示すように、 $\mu$ の値を $2.5 \%$ ○以下の領域で大きな値とし、 $\beta a$ を $10 \%$ 以下で負の值

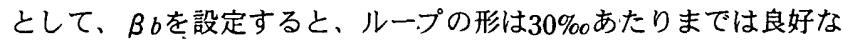
一致を示す。しかし、それを越えるとモデルの所定振幅での応力点 を実験結果にあわせて計算をしたた場合、モデルのループが実験値 のルナプの内側に収束する傾向が出始める。

\subsection{Ramberg-0sgoodモデル ${ }^{15)}$}

Fig.17にRamberg-Osgoodモデルの概念図を示す。Skeleton curveは：

$$
\frac{\varepsilon}{\varepsilon_{y}}=\frac{\sigma}{\sigma_{y}}+\alpha\left|\frac{\sigma}{\sigma_{y}}\right|^{n} .
$$

Hysteresis loopは :

$$
\frac{\varepsilon \pm \varepsilon_{a}}{2 \varepsilon_{y} .}=\frac{\sigma \pm \sigma_{a}}{2 \sigma_{y}}+\alpha\left|\frac{\sigma \pm \sigma_{a}}{2 \sigma_{y}}\right|^{n}
$$

$\alpha$ と $n$ を変化させることによって $\sigma-\varepsilon^{\prime}$ 関係の曲線の形状が決ま り、所定ひずみ振幅に対応する応力点を結ぶと、Skeletón curve上に Hysteresis loopの応力点が並ぶというものである。Table.2はSS400 材の実験結果に適合する $\alpha$ と $n$ 値を示したもので、Fig.18はその 值を用いて計算した結果を $\sigma_{t}-\varepsilon_{l}$ 関係と比較したものである。 Fig.18(a)は2.5\%， 5.0\%o，7.5\%。との比較を示し：F1g.18(b)は 10\%， 30\%o，50\%。との比較を示している。Figs.18(a),(b)より、Table.2示す ような係数を用いると、毛デルによる履歴ループの形状は実験結果 


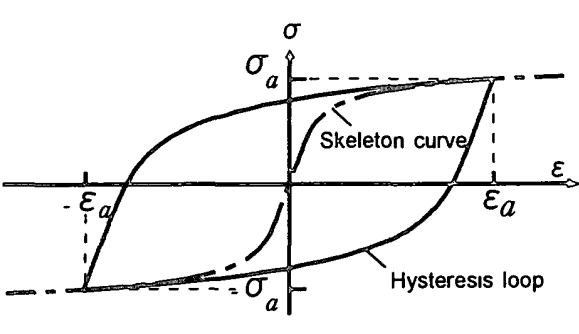

Fig.17 Ramberg-Osgood モデル概念図

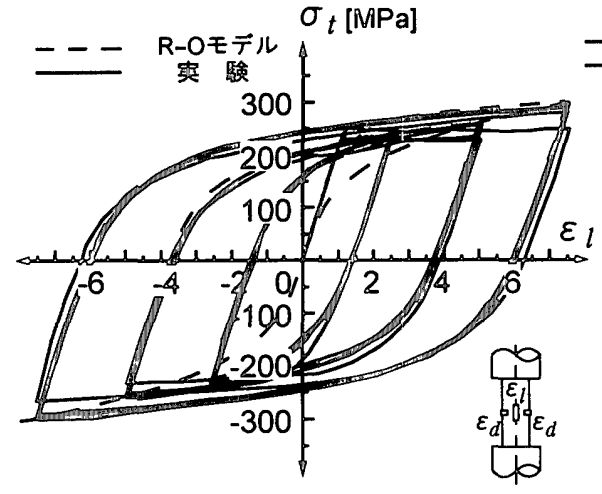

(a) $\varepsilon_{l a}=2.5 \%, 5.0 \% 0,7.5 \%$

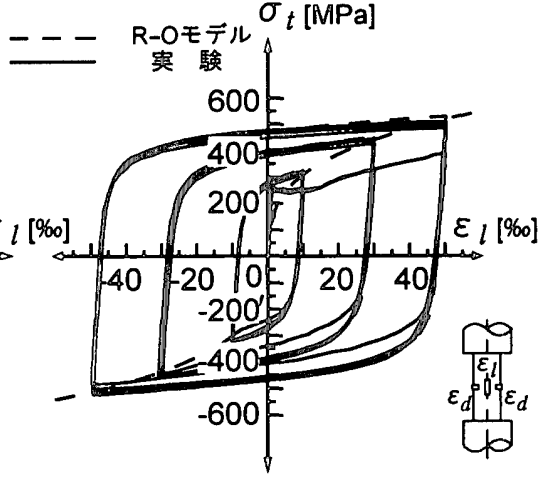

(b) $\varepsilon_{l a}=10 \%, 30 \%, 50 \%$

Fig.18 Ramberg-Osgood モデルと実験結果の比較

と一致するが、所定ひずみ時の応力点がSkeleton curve上に並ぶの は5.0\%o以上の領域であることがわかった。

\section{7. 結墖}

一般構造用鋼SS400材の塑性履歴特性を明らかにするために、円 柱形供試体を用いて中央部の局所軸ひずみ（ $\left.\varepsilon_{l}\right)$ 制御による定ひ ずみ振幅 $\left(\varepsilon_{l a}\right)$ 交番引張圧縮試験を定常ループに至るまで行なった。 公称応力 $\left(\sigma_{n}\right)$ 一局所軸ひずみ $\left(\varepsilon_{l}\right)$ 関係による塑性履歴ルー プの形状はひずみ振幅 $\varepsilon_{l a}=30 \% 0$ くらいまで原点対称性を保つ。塑 性履歴ループにおける真応力 $\left(\sigma_{t}\right)$ と公称応力 $\left(\sigma_{n}\right)$ はひずみ振 幅 $\varepsilon_{l a}=30 \%$ を越えるあたりから差が生じはじめる。公称ひずみ $\left(\varepsilon_{n}\right)$ と供試体中央部の局所軸ひずみ $\left(\varepsilon_{l}\right)$ による真ひずみが一致 するのはひずみ振幅 $\varepsilon_{l a}=10 \%$ くらいまでであることか確認できた。

破断までの絽返し数が $10^{2}$ 回以上の変形域で引張圧縮交番繰返し 載荷試験をおこなうと、公称ひずみと局所軸ひずみの履歴ループは ほぼ同じ挙動を示し、径方向ひずみの履歴ループも伸び方向や縮み 方向に偏って増加することがない。しかし、100〜 $10^{1}$ 回で破壊にい たる大変形域で、引張圧縮交番絽返し載荷試験をおこなう際に、供 試体中央部の局所軸ひずみでひずみ振幅制御を行うと、径方向の伸 び変形にエネルギーが消費され、供試体中央部の径ひずみに伸びが 累穦され、供試体全体が縮み、塑性域での体積が減少する。また、 供試体全体の公称ひずみでひずみ振幅制御を行うと、軸方向の伸び 変形にエネルギーが消費され、供試体中央部の軸ひずみに伸びが累 積し、供試体中央部が伸び、塑性域での体積が増加する。

実験で得られた履歴ループにRamberg-Osgoodモデル、IーK b1LinearモデルおよびIーK直列モデルによる履歴ループを適用した結 果、それらモデルの適用限界を示した。

\section{䭞 辞}

本研究の実施に際し、（株）神戸製鋼所より供試材料の御提供を頂 きました。ここに記して厚く御礼申し上げます。

參考文献

1) 幡中憲治,藤満達朗 . 軸およひ值径方向ひずみ制御下の低サイクル疲常と それに関する二，三の考察，日本機珹学会論文集 (A)，52巻484号， pp.2566-2573, 1986.12 .

2) Bui-Quoc, T and Biron,a * Comparison of Low-cycle Fatigue Resurts with Axual and Diametal Extensometers, Exp.Mechanics., Apnl 1978, pp.127-133, April 1978.

3）松阙三郎,湯山道也西島敏 : 低サイクル疲労におけるヤング率とポアソ 比，日本機械学会論文集（A），53巻488号,pp.724-731，1987.4.

4) Yamada, $M \cdot$ Das Hanshın-Awaj1-Erdbeben, Japan 1995 - Schaden an Hochbauten, Baungenıur.Sprnnger, Berlın, 71, pp73-80, 1996.
Table.2 変数 $\alpha, n \quad(\$ \$ 400)$

\begin{tabular}{|c|c|c|}
\hline & $\alpha$ & $n$ \\
\hline Skeleton & 2500 & 3.5 \\
\hline$\varepsilon_{l a}$ & $\alpha$ & $n$ \\
\hline $1.5 \% \circ$ & 0.700 & 9.0 \\
$2.5 \% \circ$ & 2.250 & 9.0 \\
$4.0 \% \circ$ & 1.700 & 9.0 \\
$5.0 \%$ & 1.600 & 9.0 \\
$7.5 \% \circ$ & 0.710 & 9.0 \\
$10.0 \% 0$ & 0.485 & 9.0 \\
$20.0 \% 0$ & 0.160 & 9.0 \\
$30.0 \% \circ$ & 0.020 & 11.3 \\
$40.0 \%$ & 0.002 & 13.2 \\
$50.0 \%$ & 0.001 & 13.6 \\
\hline
\end{tabular}

5）山田稳，中島伸幸 : 構造用鋼材の超低サイクル疲労破壊に関するエネルギ一 的考察一累䅡損傷エネルギーと大予ひずみの効果, 日本建築学会棈造系 論文集, 第534号, 2000.8。（掲載予定）

6)桑村仁秋山宏．延性き裂発生ひずみに及ぼす冷間塑性加工の影堙，日本 建築学会棏造系論文報告集，第454号，pp.171-178，1993.12.

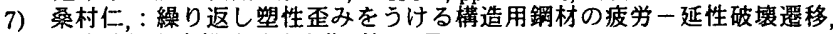
日本建築会構造系論文集, 第461号, pp.123-131, 1994.7.

8) 中込忠男,李建・繰返し力を受けるSM490龬の疲労性に関する研究，日本 建築学会構造系論文集, 第469号, pp.127-136, 1995.3 .

9）山田稔中島伸幸：銅材の超低サイクル疲労に関する研究（3龬材の基本 性質に関する検討一紟横垔み比[Po1sson数]），日本建築学会近㙨支部研 報, No.35, pp21-24, 1995.6.

10）山田稳,中島伸幸：鋼材の超低サイクル疲労に関する研究（4.龬材の基本 性質に関する検討一維横歪み比（Po1sson数））,日本建築学会大会梗概， pp. 327-328, 1995.8 .

11）山田稳,中島伸幸：鋼材の超低サイクル疲労に関する研究（7.G.L. $=2.5 \mathrm{D}$-エネルギーによる考察2），日本建築学会近畿支部研報, No.37, pp.185-188, 1997.7 .

12)河本実，田中道七・銅の引張圧縮塑性疲労試験，材料試験，第 11 巻 第105号, pp.13-23, 1962.

13）安藤掊司,中野典彦,加藤容三,広瀬素尚・炭案鐝の引張圧縮塑性疲労につ いて, 材料，第15巻第154号, pp.499-506, 1966.

14）山田稳，中島伸幸・鋼材の超低サイクル疲労に関する研究（9.Bauschinger Model II ) ，日本建築学会大会梗概, pp503-504, 1997.9.

15) MorrowJ : CYCLIC PLASTIC STRAIN ENERGY AND FATIGUE OF METALS, ASTM STP, No.378, pp.45-87, 1965.

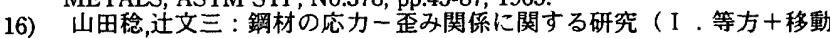
硬化モデル），日本建築学会論文報告集第270号, pp.17-22, 1978.8 .

17) TANABASHI,R. YOKOO,Y. NAKAMURA,Y. KUBOTA,T and YAMAMOTO,A : LOAD-DEFLECTION BEHAVIORS AND PLASTIC FATIGUE OF WDE-FLANGE BEAMS SUBJECTES TO ALTERNATING PLASTIC BENDING PART II HYSTERETIC AND SKELETON STRESS- STRAIN RELATIONS AND PLASTIC FATIGUE OF FLANGES, Trans. of A.IJ. No.176, pp.25-33, Oct. 1970.

18）山田稔,辻文三・等方＋移動硬化モデルによる銅材の応力ーひずみ関係, 日本建珤学会近畿支部研報, No.17, pp.253-256, 1978.5 .

19) 山田稔,辻文三・鋼材の応力ー歪み関保（II：移動硬化+等方硬化, 瑱化 モデル)，日本建築学会大会学術粪演梗概集, pp.1177-1178, 1978.9.

20) 河本実,鲤淵興二・塑性領域における疲労現象について（2）,材料,第 12 巻第117号, pp.413-420, 1963.

（2000年 1 月 10 日原稿受理, 2000 年 5 月 11 日採用決定 